\title{
Spatiotemporal analysis of the atmospheric and surface urban heat islands of the Metropolitan Area of Toluca, Mexico
}

\author{
Erika Rivera $^{1}$ (1) Xanat Antonio-Némiga ${ }^{1}$ - Gabriel Origel-Gutiérrez ${ }^{1}$. \\ Pablo Sarricolea $^{2} \cdot$ Salvador Adame-Martínez $^{1}$
}

Received: 7 July 2016/ Accepted: 28 February 2017/Published online: 10 March 2017

(c) Springer-Verlag Berlin Heidelberg 2017

\begin{abstract}
The dynamic of consolidation of urban areas in Latin America has allowed that almost $80 \%$ of the population concentrates in cities; this has produced changes in land covers and modified regional climate, propitiating the appearance of urban heat islands. The Metropolitan Area of Toluca, State of Mexico, Mexico, holds the fifth national place in population size and experiences this process, because of this, the objective is to analyze and compare the spatiotemporal characteristics of the atmospheric urban heat island obtained from data gathered from 12 urban and rural weather stations with the surface urban heat island obtained from the digital processing of four Landsat 8 images. Results show the year-round presence of night-time atmospheric urban heat islands, which reach a peak in autumn (up to $6{ }^{\circ} \mathrm{C}$ ). Daytime atmospheric urban heat islands occur in summer and autumn with a maximum intensity of $4{ }^{\circ} \mathrm{C}$. For their part, surface urban heat islands occur in spring, summer and autumn and reach maximums of $19{ }^{\circ} \mathrm{C}$ in intensity. A strong correlation was found between wetness and surface temperature (coefficient of determination, 0.8 ) in spring and winter. Soil wetness directly impacts the formation of weak urban heat islands in dry season, and intense ones in wet season, while the green areas and the winds affect the spatial distribution of the same.
\end{abstract}

Keywords Atmospheric temperature - Surface temperature - Urban heat island intensity · Urban climate . Soil wetness

Erika Rivera

valerika02@hotmail.com

1 Universidad Autonoma del Estado de Mexico, Toluca, Mexico

2 Universidad de Chile, Santiago, Chile

\section{Introduction}

The growth of urban populations around the globe is undeniable and consolidates in Latin America and the Caribbean, which nowadays is considered the most urbanized region in the world, for almost $80 \%$ of its population lives in cities (UN HABITAT 2012). However, many cities expanded without taking into consideration a proper planning that ensured the population's quality of life. The expansion of the city modified land use and land cover and changed the albedo of the surface as the coverage of green areas decreased, and with this evapotranspiration, wind regime and surface runoff modified; besides, the sources of anthropogenic heat increased (Oke 1987; López et al. 1993; Fernández and Martilli 2012). This impacts the regional conditions of climate, generating a local urban weather. According to Romero et al. (2010) "Urban climate comes from unnoticed and intentional transformations introduced into local and regional climates, which directly relate with the social construction of spaces and places." All urban climates present common characteristics, being urban heat island its main feature (Oke 1987; López et al. 1993; Montávez et al. 2000). An urban heat island is defined as an urban area with higher temperature conditions than neighboring non-developable areas (Voogt and Oke 2003). There are two sorts of urban heat islands. The first, atmospheric urban heat island (UHI), represents the differences in air temperature between urban and rural areas. The second, known as surface urban heat island (SUHI), shows thermal differences between artificial surfaces (such as asphalt and rooftops) and the natural ones (such as vegetation and cultivations) (Fernández and Martilli 2012). The most significant when analyzing a heat island features is the shape, intensity and variations in space and time (López et al. 1993; Voogt 2008). 
To identify UHI, data on atmospheric temperature measured by thermometers are needed; some works have obtained them from fixed weather stations (Montávez et al. 2000; Sarricolea and Martín-Vide 2013; Colunga et al. 2015), or else from transects with mobile stations (Alonso et al. 2003; Ruiz-Flaño et al. 2008). On the contrary, the value of SUHI is estimated from images obtained by means of remote sensors using the thermal infrared region. Among the most used satellites utilized for this purpose are Landsat (Zhang and Wang 2008; Jiménez-Muñoz et al. 2010; Gioia et al. 2014), MODIS (Zhao et al. 2014; Sarricolea and Martín-Vide 2014), NOAA (García-Cueto et al. 2007) and ASTER (Nichol et al. 2009).

The objective of this paper is to analyze the spatiotemporal behavior of UHI and SUHI in the Metropolitan Area of Toluca, Mexico, throughout the four seasons of 2014 in order to explain the magnitude and seasonality of the temperature variations in a heavily urbanized territory.

\section{Methodology}

\section{Study area}

The Metropolitan Area of Toluca (MAT) is the fifth larger populated area in Mexico. It is located in the central region of the country, in the State of Mexico; it comprises 15 municipalities, over a surface of $2204.2 \mathrm{~km}^{2}$, of which $402.7 \mathrm{~km}^{2}$ correspond to artificial surface (Fig. 1); it is at an altitude between 2600 and 3000 m.a.s.l. The surrounding vegetated areas are mainly composed by induced grasslands, seasonal and irrigated agriculture and forest and protected areas, over a surface of $1801 \mathrm{~km}^{2}$.

According to Morales et al. (2007), the atmosphere of the zone presents important dynamism, because it is located in a place where phenomena from cold, temperate and tropical thermal zones converge. The climate is sub-humid temperate with summer rains, an annual mean temperature of $12.0^{\circ} \mathrm{C}$ and an annual mean precipitation of $760 \mathrm{~mm}$ that takes place between the months of May and October.

In 2010, MAT had a population of 1,936,126 inhabitants and an annual mean growth rate of $2.2 \%$ according to data from SEDESOL et al. (2012). In the 1980's, the population growth was lead by the establishment of the Toluca-Lerma industrial area, and then it diversified toward the tertiary sector reaching peripheral municipalities. In 2010 , it had a population density of 813.6 inhab $/ \mathrm{km}^{2}$ (GEM and COESPO 2012).

\section{Data}

For the heat islands to reach their maximum intensity there should be anticyclonic weather with still air and clear sky conditions, which allows a better insolation of the surface
(López et al. 1993). According to García-Cueto et al. (2007), the most representative months for the northern hemisphere are: January (winter), April (spring), July (summer) and October (autumn). Therefore, in order to choose the days to analyze, the anticyclonic conditions of the atmosphere and the representative months of the year were taken into account.

To verify that the day chosen met the still air requirements, the formula by Oke and Hannell (1970) was used; it determines the wind speed limit from which the urban heat island can dispel in function of the population size and expresses as:

$U=(3.4 \log P)-11.6$

where $U$ is the critical wind speed in $\mathrm{m} / \mathrm{s}$ and $P$ is the city's population. According to official data, in 2010 the population of the metropolis was $1,936,126$ inhabitants and its annual mean growth rate was $2.2 \%$; this way, the projection for 2014 was 2,112,211 inhabitants, and then the speed limit for MAT is $9.9 \mathrm{~m} / \mathrm{s}$. Data for wind speed, provided by Red Automática de Monitoreo Atmosférico de Toluca (RAMA) (Toluca's Automatic Network of Atmospheric Monitoring), for the selected dates, oscillated between 2.9 and $4.5 \mathrm{~m} / \mathrm{s}$, so they are under the speed limit, which allows the formation of heat island. To meet the requirement of clear sky, satellite images devoid of clouds in the study area were selected. This process allowed determining the days to be analyzed (Table 1).

\section{Atmospheric temperature}

To identify the UHI's, data on the highest and lowest temperatures were collected from 12 automatic urban and rural weather stations (Fig. 2), which belong to three institutions: RAMA, Comisión Nacional del Agua (CONAGUA) (National Water Commission) and Instituto Nacional de Investigaciones Forestales, Agrícolas y Pecuarias (INIFAP) (National Institute of Forest, Agricultural and Livestock Researches). The name, location and type of station are presented in Table 2.

To analyze the heat island, its intensity has to be measured. Oke (1987) defines intensity as the difference between the highest temperature in the urban and rural environments for stable atmospheric conditions and after sunset. Montávez et al. (2000) retake Oke's proposal, but integrate all the meteorological conditions in which this maximum difference exists by means of Eq. 2:

$\Delta T=T_{\mathrm{U}}-T_{\mathrm{R}}$

where $\Delta T$ is the intensity of the urban heat island, $T_{\mathrm{U}}$ is the urban temperature and $T_{\mathrm{R}}$ is the rural temperature. Data for the highest and lowest temperatures were utilized to detect daytime and night-time urban heat islands, respectively. To standardize the process, the lowest temperature in rural 


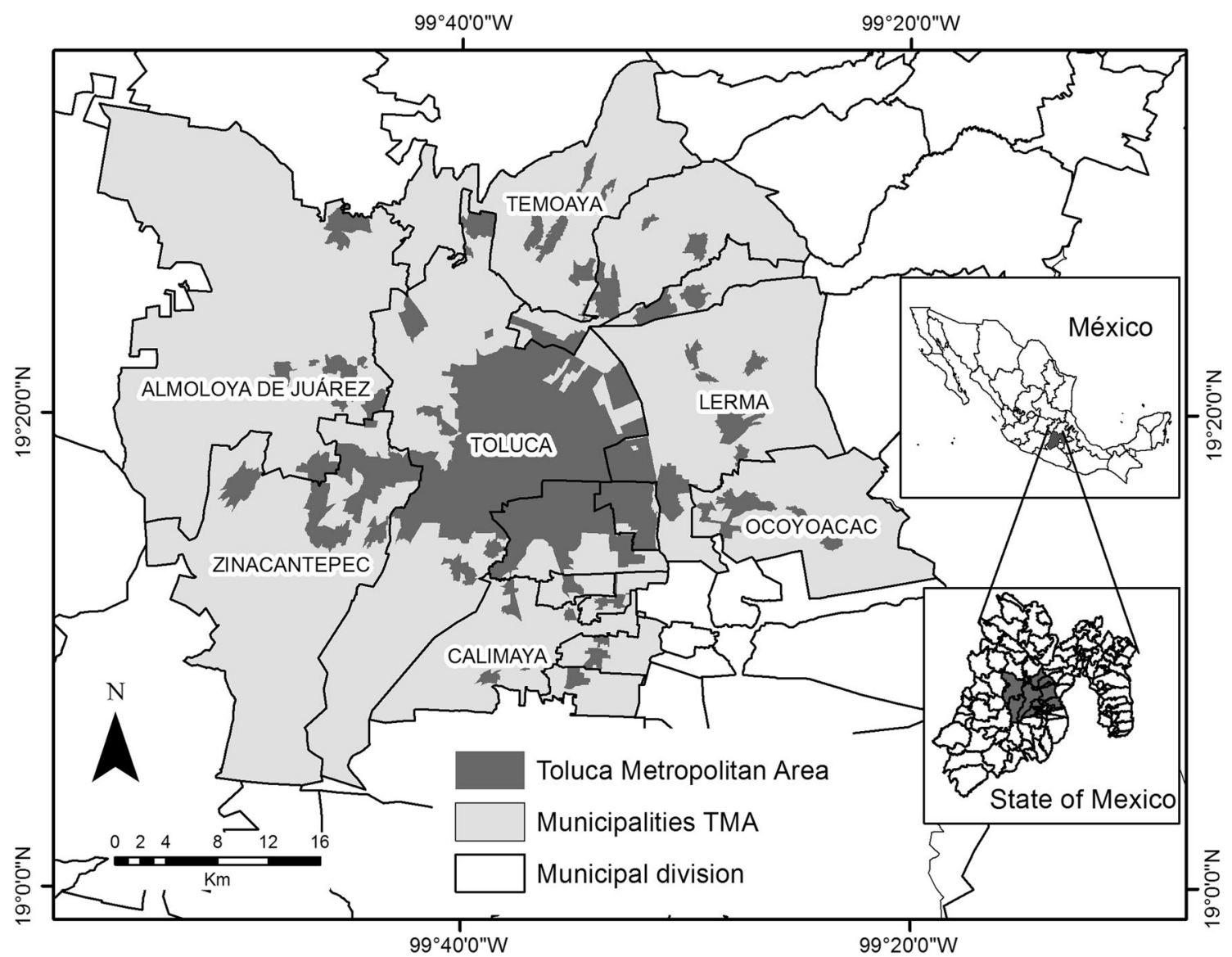

Fig. 1 Geographic location of the Metropolitan Area of Toluca, Mex

Table 1 Study dates with anticyclonic conditions

\begin{tabular}{lll}
\hline Season & Month & Day \\
\hline Winter & January & 31 \\
Spring & April & 21 \\
Summer & July & 26 \\
Autumn & October & 30 \\
\hline
\end{tabular}

stations (Arroyo) was identified, and this value was taken as a constant for the subtraction. For the spatial distribution of the urban heat island, an interpolation of data was run in the program ArcGis 10.1. The method was ordinary kriging, as it produces a smaller error while performing the process (Anderson 2002). The values of urban heat island intensity were classified following Fernández (1995), as weak $\left(0-2{ }^{\circ} \mathrm{C}\right)$, moderate $\left(2.1-4{ }^{\circ} \mathrm{C}\right)$, strong $\left(4.1-6{ }^{\circ} \mathrm{C}\right)$ and very strong $\left(>6^{\circ} \mathrm{C}\right)$. Values below zero are classified as negative urban heat islands.

\section{Surface temperature}

To identify the SUHI's, the surface temperature is required; it was obtained from four Landsat 8 images (path 26, row
47), on the previously mentioned dates; these images are level $1 \mathrm{~T}$, this is to say, they have geometric and radiometric corrections; thus, these are ortho-rectified digital images (USGS 2015). For temperature derivation, the bands of thermal infrared between 10 and $12 \mu \mathrm{m}$ (band 10 and 11) are utilized and processed in software ENVI 5.1. The procedure to estimate the temperatures is based on measuring the electromagnetic radiation emitted by the surface of the body in function of its temperature (Olalla and Calera 2005). For the surface temperature derivation, Chuvieco (2002) indicates the following procedure:

(a) Code digital levels (DN) to radiance to find the relation between the flow emitted and received by the sensor. USGS (2015) refers that for the case of Landsat 8, the bands of sensors OLI and TIRS can be turned into TOA spectral radiance using the rescaled radiance factors included in the metadata of the image using the following equation:

$L_{\lambda}=M_{L} Q_{\text {cal }}+A_{L}$

On this equation, $L_{\lambda}=$ TOA represents spectral radiance $\left[\mathrm{W} /\left(\mathrm{m}^{2} \operatorname{srad} \mu \mathrm{m}\right)\right] . \quad M_{L}=$ band-specific multiplicative rescaling factor from the metadata 


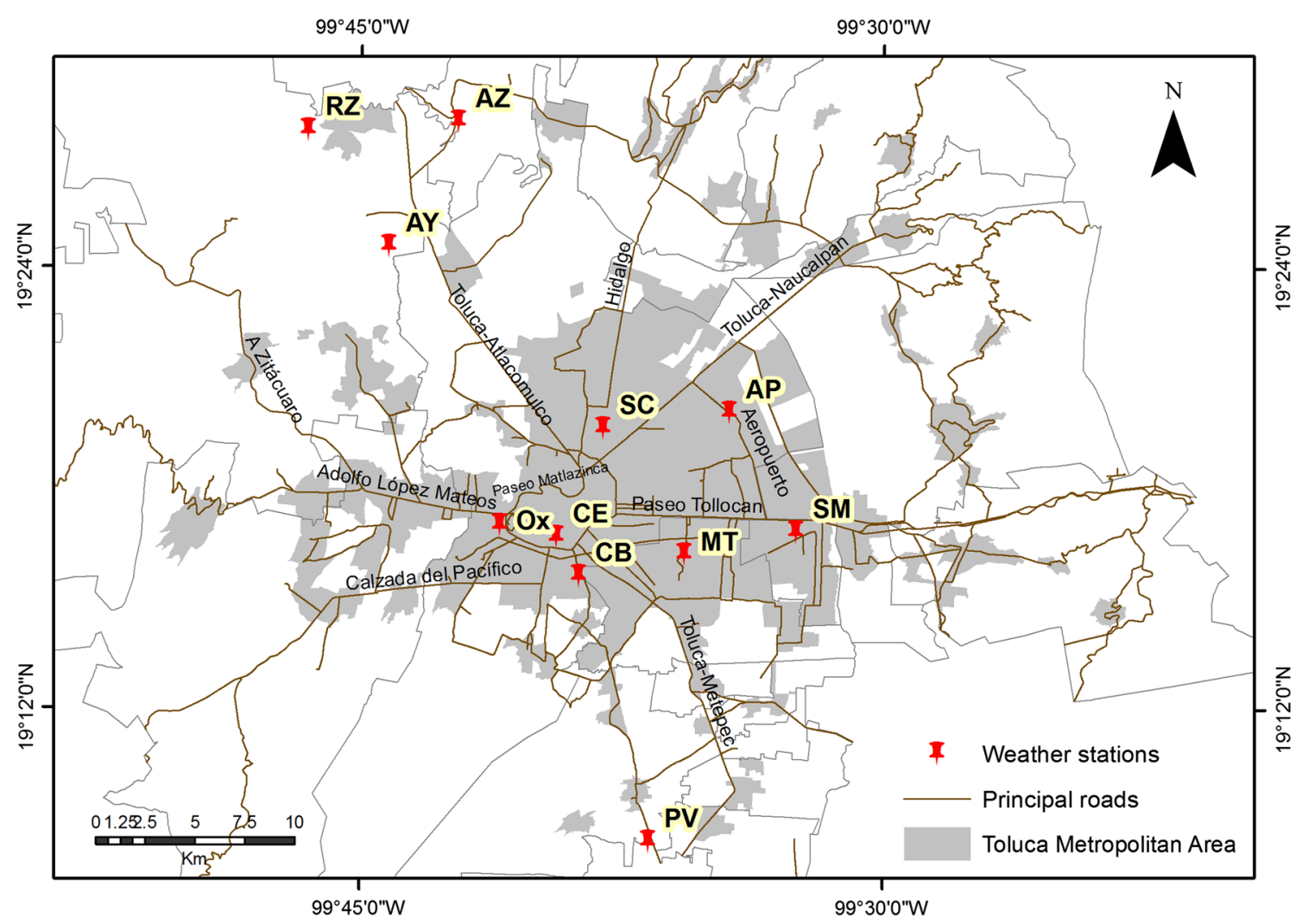

Fig. 2 Geographic location of weather stations and principal roads

Table 2 Name, type and location of weather stations in study area

\begin{tabular}{llllll}
\hline Station & Symbology & Type & Latitude N & Longitude O & Altitude m.a.s.l. \\
\hline Oxtotitlán & OX & Urban & $19^{\circ} 17^{\prime}$ & $99^{\circ} 41^{\prime} 05^{\prime \prime}$ & 2701 \\
Toluca-Centro & CE & Urban & $19^{\circ} 16^{\prime} 41^{\prime \prime}$ & $99^{\circ} 39^{\prime} 23^{\prime \prime}$ & 2676 \\
Metepec & MT & Urban & $19^{\circ} 16^{\prime} 12^{\prime \prime}$ & $99^{\circ} 35^{\prime} 42^{\prime \prime}$ & 2610 \\
Ceboruco & CB & Urban & $19^{\circ} 15^{\prime} 37^{\prime \prime}$ & $99^{\circ} 38^{\prime} 44^{\prime \prime}$ & 2679 \\
San Mateo Atenco & SM & Urban & $19^{\circ} 16^{\prime} 49^{\prime \prime}$ & $99^{\circ} 32^{\prime} 30^{\prime \prime}$ & 2575 \\
Aeropuerto & AP & Urban & $19^{\circ} 20^{\prime} 4^{\prime \prime}$ & $99^{\circ} 34^{\prime} 26^{\prime \prime}$ & 2583 \\
San Cristobal Huichochitlán & SC & Urban & $19^{\circ} 19^{\prime} 38^{\prime \prime}$ & $99^{\circ} 38^{\prime} 3^{\prime \prime}$ & 2613 \\
Providencia & PV & Rural & $19^{\circ} 8^{\prime} 22^{\prime \prime}$ & $99^{\circ} 36^{\prime} 43^{\prime \prime}$ & 2609 \\
Arroyo & AY & Rural & $19^{\circ} 24^{\prime} 34^{\prime \prime}$ & $99^{\circ} 44^{\prime} 12^{\prime \prime}$ & 2555 \\
Ignacio Ramirez & RZ & Rural & $19^{\circ} 27^{\prime} 45^{\prime \prime}$ & $99^{\circ} 46^{\prime} 33^{\prime \prime}$ & 2574 \\
Alzate & AZ & Rural & $19^{\circ} 27^{\prime} 59^{\prime \prime}$ & $99^{\circ} 42^{\prime} 14^{\prime \prime}$ & 2666 \\
\hline
\end{tabular}

(radiance_mult $=3.3420 \mathrm{e}-04) . A_{L}=$ band-specific additive rescaling factor from the metadata (radiance_add $=0.10000$ ) and $Q_{\text {cal }}=$ quantized and calibrated standard product pixel values (DN) (quantize_cal_$\max =65,535)$ (quantize_cal_min $=1$ ).

(b) Determine brightness temperature (radiant temperature) which is the estimated temperature in function of radiance from the inversion of Plank's law equation:

$T=\frac{K_{2}}{\ln \left(\frac{K_{1}}{L_{\lambda}}+1\right)}$ where $T=$ at-satellite brightness temperature $(\mathrm{K}), L_{\lambda}=\mathrm{TOA}$ spectral radiance $\left[\mathrm{W} /\left(\mathrm{m}^{2}\right.\right.$ srad $\left.\left.\mu \mathrm{m}\right)\right], \quad K_{1}=$ band-specific thermal conversion constant $(\mathrm{B} 10=774.89$, $\mathrm{B} 11=480.89 \mathrm{~W} / \mathrm{m}^{2}$ sr $\left.\mu \mathrm{m}\right)$ and $K_{2}=$ band-specific thermal conversion constant $(\mathrm{B} 10=1321.08, \mathrm{~B} 11=1201.14 \mathrm{~K})$.

(c) According to Olalla and Calera (2005), radiant temperature does not consider the emissivity of the surface nor the influence of the atmosphere; hence, such correction is needed. The two Landsat 8 thermal bands allow, for the first time, atmospheric correction using split-window techniques (Roy et al. 2014). 
For the present work, the NEM method was used; proposed by Gillespie (1985), it calculates the temperature of each pixel and band using an initial emissivity value in views of obtaining the estimated surface temperature and new emissivity values; it is developed through the following equation (Jiménez-Muñoz et al. 2003):

$B_{i}\left(T_{\mathrm{s}}\right)=\frac{L_{i}^{\text {sup }}-\left(1-\varepsilon_{\text {inicial }}\right) L_{i}^{a t m \downarrow}}{\varepsilon_{\text {inicial }}}$

where $B_{i}$ is Plank's function of radiation that a black body emits in the thermal band to consider; $T_{\mathrm{S}}$ is surface temperature; $L_{i}^{\text {sup }}$ corresponds to the radiance emission of the surface of the considered thermal band; $\varepsilon_{\text {initial }}$ is the initial emissivity value (0.96); $L_{i}^{\text {atm } \downarrow}$ indicates the descending atmospheric radiance. From the results, it is possible to obtain the values of surface temperature for each thermal band taking the maximum value for $T_{\mathrm{s}}$

$T_{\mathrm{s}}=\max \left(T_{\mathrm{s}, i}\right)$

Surface temperature is in $\mathrm{K}$, so it was transformed into ${ }^{\circ} \mathrm{C}$ subtracting 273.15. The value of the pixel for the point corresponding to each of the stations was obtained from the thermal image. The value of the same rural station used for the calculation of intensity of UHI was chosen, and it was subtracted to all the images to obtain the intensity of SUHI. Bearing in mind that the satellite pass over the study zone takes place at 12:00 h. (local time), the surface urban heat island is diurnal.

\section{Results and discussion}

Temperature behaves differently over the seasons and also during day and night due to the changing atmospheric conditions, solar inclination and the thermal processes generated in the various sorts of surfaces in the territory.

\section{Distribution of heat islands}

The heat islands can take different forms in the territory, according to types of temperature and the spatial characteristics (López et al. 1993; Voogt 2008). Atmospheric and surface temperature in MAT enables the formation of urban heat islands with various intensities and shapes, and their distribution over the territory changes as seasons pass, allowed by the environmental conditions in which they develop. According to Arnfield (2003), there is a possibility that a similarity between the spatiotemporal of the UHI and SUHI patterns is present, but will never be exact because the SUHI's will always be stronger and have greater spatial variability. In Table 3, we present the characteristics of the heat islands that appear in each season according to the sort of temperature analyzed.

\section{Daytime heat islands}

Figure 3 shows the behavior of daytime UHI and SUHI. In spring, temperature generates negative intensity values virtually over the entire urban territory. The highest values are located in the southern portion of the MAT (PV station) which comprises rural areas, reaching an intensity of $0.09{ }^{\circ} \mathrm{C}$; the lowest intensity values are for $\mathrm{CB}$ station, with $-4{ }^{\circ} \mathrm{C}$, showing little variation between urban and rural temperatures.

In surface temperature, the maximum intensity reached is $13.15{ }^{\circ} \mathrm{C}$, most of the city displays intensities between 2 and $4{ }^{\circ} \mathrm{C}$. In rural zones, there are vast areas with values above $6^{\circ} \mathrm{C}$, as in atmospheric temperature; however, there are well-defined areas in the city where same condition takes place, this is the case of the airport, located in the northeast, and some industrial parks located between Paseo Tollocan and the Airport, as well as others located on Toluca-Naucalpan highway (see Fig. 3).

Table 3 Basic characteristics of UHI and SUHI in the study area

\begin{tabular}{llllll}
\hline Urban heat island & Season & Location & Shape & Max intensity $\left({ }^{\circ} \mathrm{C}\right)$ & Min intensity $\left({ }^{\circ} \mathrm{C}\right)$ \\
\hline Daytime UHI & Spring & Entire urban area & Concentric & 0.09 & -4 \\
& Summer & Northwest of urban area & Concentric & 4.3 & -2 \\
& Autumn & North and East & Concentric & 1.3 & -0.4 \\
& Winter & Entire urban area & Concentric & 1.4 & -3.7 \\
Daytime SUHI & Spring & Center-Northeast & Irregular & 13.1 & -23.05 \\
& Summer & Center & Radial & 19.2 & -19.9 \\
& Autumn & Center, East and Northeast & Radial & 17.2 & -15.4 \\
& Winter & Center & Irregular & 13.5 & -24.6 \\
Night-time UHI & Spring & Center-East and South & Concentric & 2.5 & -2.5 \\
& Summer & Northeast and Southeast & Concentric & 5.6 & -0.2 \\
& Autumn & Center-East & Concentric & 6.4 & -0.2 \\
& Winter & Center-East and South & Concentric & 4.1 & -1.6 \\
\hline
\end{tabular}




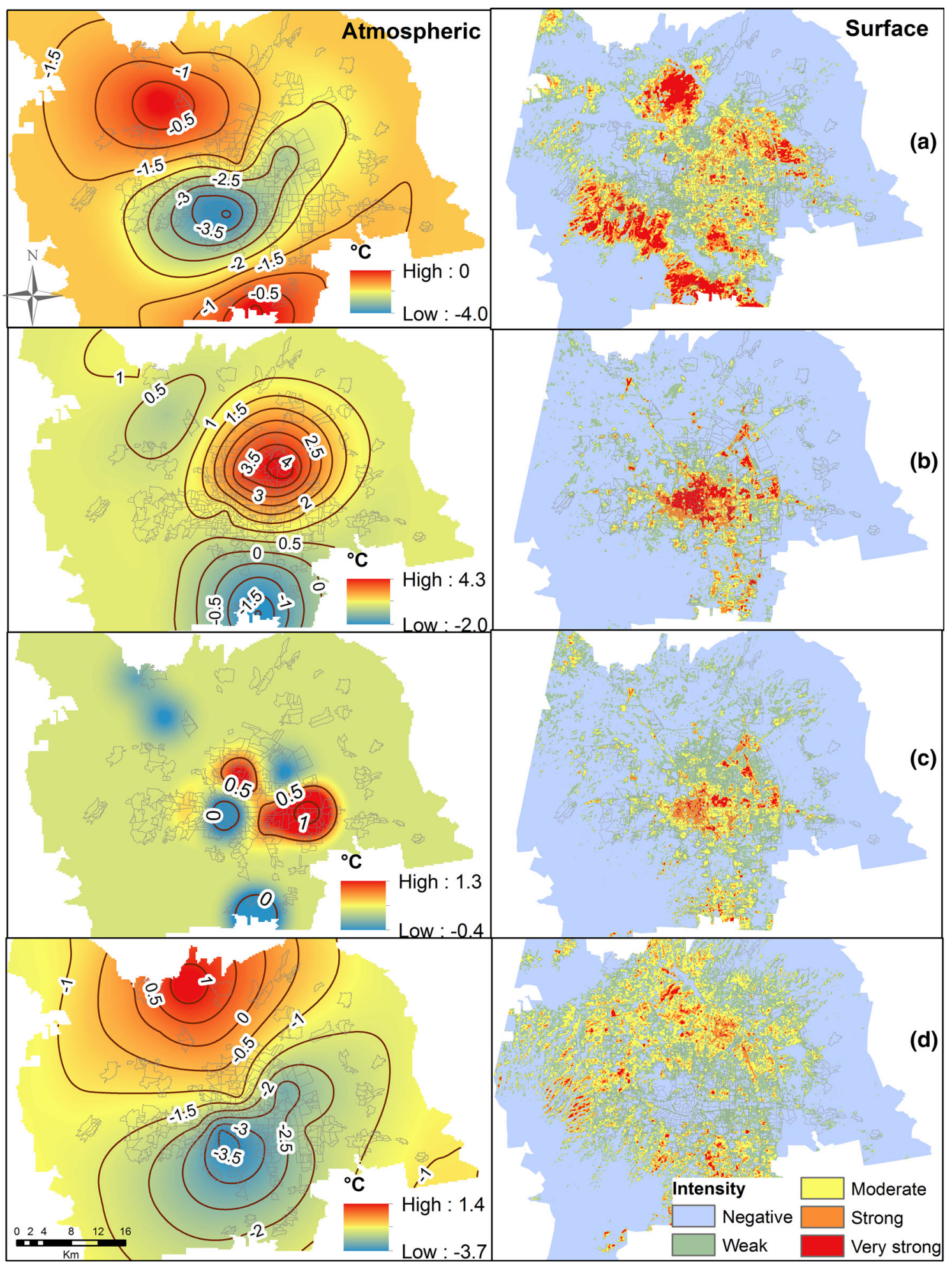

Fig. 3 Intensity of a spring, b summer, c autumn and d winter, daytime atmospheric (UHI) and surface urban heat islands (SUHI) in 2014

In summer, heat islands concentrate in the city. The UHI reaches $4.3{ }^{\circ} \mathrm{C}$ of intensity toward the northeastern metropolis, in the zone of the airport, from there it dispels in a concentric manner until it reaches intensities of $2-4{ }^{\circ} \mathrm{C}$ toward Paseo Tollocan in the south. The lowest temperatures are located in the vicinity, to the south, with intensities of $-2{ }^{\circ} \mathrm{C}$ in Providencia station (PV). In relation to the SUHI, the entire central area of the city presents intensities from strong to very strong, prevailing the latter; the maximum intensity recorded for the territory is 
$19.18^{\circ} \mathrm{C}$. The intensity over $6{ }^{\circ} \mathrm{C}$ follows a radial pattern limited by the main roads of the metropolis; it is defined by means of Paseo Tollocan to Toluca-Mexico highway; to the north by Paseo Matlazincas, following the direction of Toluca-Atlacomulco highway; to the east it comprehends from the industrial zone to the airport; to the south the pattern extends along Toluca-Metepec highway; the rural area shows an intensity from 2 to $0{ }^{\circ} \mathrm{C}$ or lower.

In autumn, there is an UHI with negative to weak intensity. The lowest temperatures are located in rural areas with intensity of $-0.4{ }^{\circ} \mathrm{C}$ (PV, RZ and AY stations), even though urban zones with the same behavior are also identified, such as the area of Toluca-centro station and the one in the airport. The maximum intensities $\left(1.3^{\circ} \mathrm{C}\right)$ locate around SM and MT weather stations on Paseo Tollocan. As for surface temperature, an urban heat island is produced inside the city with intensities from $4{ }^{\circ} \mathrm{C}$ to more than $6{ }^{\circ} \mathrm{C}$. The maximum intensity is $17.2^{\circ} \mathrm{C}$, along the Toluca-Lerma industrial corridor limited by Paseo Tollocan; unlike the UHI, the area of the airport shows intensities over $6{ }^{\circ} \mathrm{C}$. The rural environment shows negative values, except for the zone around PV weather station, where there are intensities between 2 and $4{ }^{\circ} \mathrm{C}$.

Finally, in winter and for UHI, the maximum intensity is $1.4{ }^{\circ} \mathrm{C}$ and takes place in the rural environment, specifically in AZ station, which as a set with RZ and AY weather stations produce an urban heat island with intensities from 0 to $1.4^{\circ} \mathrm{C}$. The rest of the territory, including the city, behaves with an intensity below $0{ }^{\circ} \mathrm{C}$; the lowest values concentrate in an area limited by $\mathrm{OX}, \mathrm{CE}, \mathrm{MT}$ and $\mathrm{CB}$ weather stations, this last has the lowest intensity in the zone $\left(-3.7^{\circ} \mathrm{C}\right)$. For SUHI, the behavior is similar, the highest intensities located in the vicinity of the city reaching up to $13.5^{\circ} \mathrm{C}$. In the urban zone negative values occur in the area limited by $\mathrm{OX}, \mathrm{CE}$ and $\mathrm{CB}$ stations and on Paseo Matlazincas; in the zones that correspond to SC, MT and SM stations, an urban heat island of $0-2{ }^{\circ} \mathrm{C}$ appears. Some spaces in the urban area with intensities of $4^{\circ} \mathrm{C}$ and over $6{ }^{\circ} \mathrm{C}$ are identified. Among the most distinguishable the airport surroundings and the industrial zone along Paseo Tollocan.

\section{Night-time urban heat islands}

The night-time UHI's (Fig. 4) show in spring, negative values in the northwest part, between $A Y, R Z$ and $A Z$ stations. A maximum intensity of $2.5^{\circ} \mathrm{C}$ is reached, it is located along CE, CB, MT and SM weather stations following Paseo Tollocan; the rest of the territory presents differences in intensity between 0 and $2{ }^{\circ} \mathrm{C}$.

For summer, intensities over $4{ }^{\circ} \mathrm{C}$ concentrate in the zone of the airport (AP), where an intensity of $5.6^{\circ} \mathrm{C}$ is reached and in the surroundings of $\mathrm{OX}$ station. The rest of the metropolis exhibits intensities between 2 and $4{ }^{\circ} \mathrm{C}$, and the minimal values locate in rural areas to the northwest of the zone with $-0.2^{\circ} \mathrm{C}$.

In autumn, virtually the entire the city experiences a moderate-to-intense urban heat island. Intensities from 2 to $4{ }^{\circ} \mathrm{C}$ are in the periphery of the urban zone; around stations $\mathrm{AP}, \mathrm{SC}, \mathrm{OX}, \mathrm{CE}$ and $\mathrm{CB}$ there are intensities from 4 to $6{ }^{\circ} \mathrm{C}$, the highest intensity $\left(6.4^{\circ} \mathrm{C}\right)$ takes place in the area of influence of MT station. For rural the behavior becomes intensities from 0 to $2{ }^{\circ} \mathrm{C}$, reaching a minimal of $-0.2{ }^{\circ} \mathrm{C}$ in the northwest of the zone.

In winter, most of the urban territory shows intensities from 2 to $4{ }^{\circ} \mathrm{C}$; periphery displays low values, from 0 to $1{ }^{\circ} \mathrm{C}$, including the rural sector (PV station); in the northwest sector, which comprises RX, AY and AZ stations, there are negative values that reach $-1.7^{\circ} \mathrm{C}$. The highest intensity $\left(4.1^{\circ} \mathrm{C}\right)$ is located around station $\mathrm{CE}$, corresponding to the city downtown.

\section{Size of urban heat islands}

The municipalities comprised in the MAT occupy a surface of $2204.2 \mathrm{~km}^{2}$ of the State, of which $702.4 \mathrm{~km}^{2}$ correspond to urban areas and $1801 \mathrm{~km}^{2}$ to rural. Figure 5 shows the intensity that prevails in each station and the percentage it holds in the territory. Taking into consideration the daytime UHI, it behaves negatively in spring, $100 \%$ of the territory shows such values. In summer, the largest extension $(61.7 \%)$ is occupied by a weak urban heat island, the maximum intensity developed is strong and extends over $2.2 \%$ of the urban territory; in autumn, the intensity of the urban heat island is weak and it occurs in $96.2 \%$ of the urban territory; in winter, $95.6 \%$ of the territory is occupied by a negative island and the maximum intensity (weak) develops in $4.2 \%$ of the city.

As for SUHI, the intensity values reached are higher as UHI's with strong intensity appear over the year; in spring it is $7.7 \mathrm{~km}^{2}$, which corresponds to $1.9 \%$ of the urban territory, even though the largest part of the territory is covered by a weak island with $30.2 \%$; in summer, the largest SUHI in the year generates, it reaches very strong intensity and covers an extension of $8 \%$ of the territory; autumn also has a very strong SUHI; however, the extension of $2.2 \%$ of the urban zone, the largest percentage of the territory $(36.6 \%)$ presents weak intensity; in winter, the negative surface urban heat island covers $40.4 \%$ of the space, albeit in $4.5 \%$ of the territory a strong island and another less intense than $1 \%$ generate.

In relation to the behavior of the night-time UHI, in spring the maximum intensity reached is moderate, with $20.8 \%$ of extension, while most of the territory is occupied by an urban heat island weak in intensity. In summer, there is a strong urban heat island in $33.8 \%$ of 


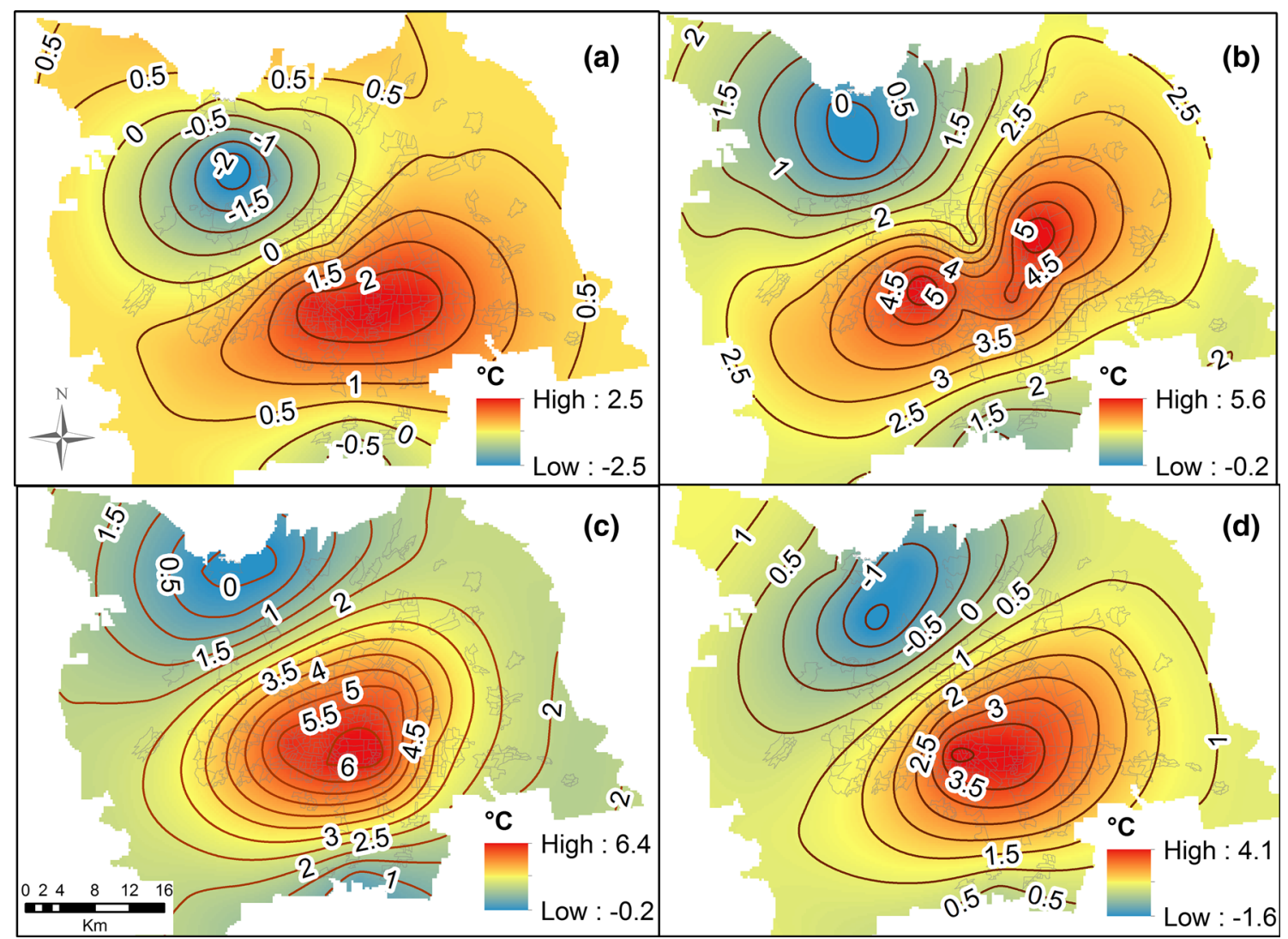

Fig. 4 Intensity of a spring, b summer, c autumn and d winter night-time UHI's in 2014
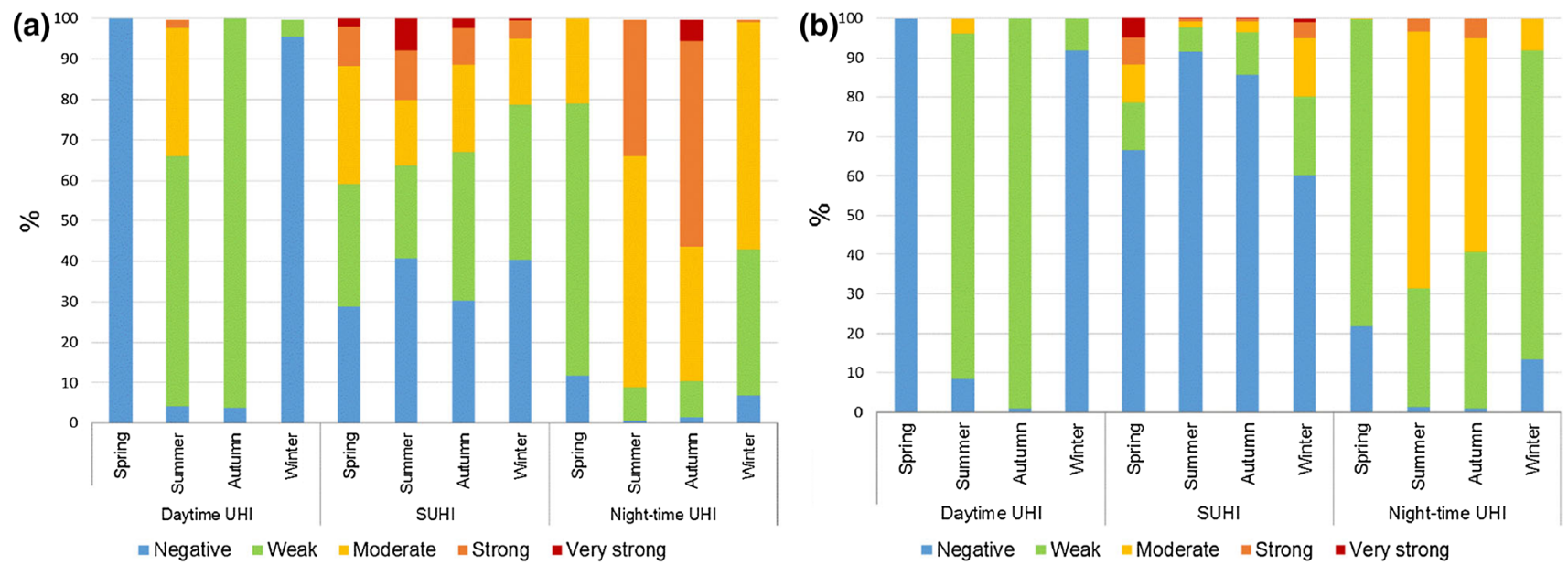

Fig. 5 Percentage of $\mathbf{a}$ urban and $\mathbf{b}$ rural territory by season, occupied by heat islands according to intensity

the city and another moderate that covers the most extension in the territory (57\%). In autumn, there is a very strong island with an extension of $21.7 \mathrm{~km}^{2}$, which represents $5.4 \%$ of the urban zone, mostly $(50.8 \%)$ occupied by a strong island. Finally, in winter $56.3 \%$ of the urban territory presents a moderate urban heat island; however, a strong micro-island manages to form in $2.4 \mathrm{~km}^{2}$ in the city.
On occasions, warmer conditions in the rural area are more notorious than in the city, producing non-urban heat islands, as there are conditions of scant wetness and/or vegetation in the soil, which enables heating in an accelerated manner (Peña and Romero 2005). In MAT, these conditions are in SUHI's (Fig. 5), where it is noticed that the most intense and with the largest surfaces appear in spring and winter, which are dry season in Mexico. UHI's 
present diverse data because in the interpolation most values were generated from the stations located in the urban area, so the isotherms extend to rural areas.

\section{Seasonality and intensity of heat islands}

Currently, there is no consensus on the seasonality and the maximum intensity of a heat island, because its formation varies over time and space according to the specific characteristics of the physical and social environment, such as geographic location, urban characteristics and meteorological conditions (Oke 1987). Moreover, seasons have a fundamental weight on the intensity values reached, due to radiation, land cover and the atmospheric conditions (EPA 2013).

The behavior of the heat islands for the MAT for 2014 is defined on the basis of geographic distribution, size and intensity values (Table 4). Daytime UHI is negative in spring, it reaches the highest intensity in summer; for winter, it was determined that the behavior is negative in spite of the presence of a weak island, as the latter is very close to a rural station, this way the interpolation process may have influenced the distribution. In relation to SUHI, the behavior in spring was determined as moderate due to the extension and location of the island, even though there are higher intensities, which distribute very dispersedly as micro-islands. For summer and autumn, there are islands with maximum intensity (very strong) and for winter, despite there are micro-islands with intensity from weak to strong, it is concluded that the negative intensity prevails as it occupies $40 \%$ of the territory, which is located in the most representative part of MAT. Finally, the behavior of night-time UHI is moderate in spring, increases to strong in summer, reaches a maximum intensity in autumn and in winter moderate intensity prevails due to its extension and location.

In respect to the process of urban heat island formation, some authors indicate that it is at night when the process of urban heating takes place (Jauregui 2005; Romero et al. 2010; Sarricolea and Martín-Vide 2013), as it is when the maximum intensities have been reported, reaching average values between 1 and $3{ }^{\circ} \mathrm{C}$ and in anticyclonic conditions up to $12{ }^{\circ} \mathrm{C}$ (Voogt 2008). For MAT, the pattern is reproduced, generating night-time urban heat islands over

Table 4 Temporality and intensity of heat islands of 2014 in Metropolitan Area of Toluca

\begin{tabular}{llll}
\hline & Daytime UHI & SUHI & Night-time UHI \\
\hline Spring & Negative & Moderate & Moderate \\
Summer & Strong & Very strong & Strong \\
Autumn & Weak & Very strong & Very strong \\
Winter & Negative & Negative & Moderate \\
\hline
\end{tabular}

the year, with high intensities for summer and autumn, being $6.3^{\circ} \mathrm{C}$ the maximum for the latter. Seasonality of night-time UHI varies according to the characteristics of each city; there are works that report the same seasonality as the one detected for Toluca, where the maximum intensity takes place in autumn with values between 2 and $4.5^{\circ} \mathrm{C}$ (Alonso et al. 2003; García-Cueto et al. 2007; Sarricolea and Martín-Vide 2014); other authors identify it in summer and spring (Sarricolea and Martín-Vide 2013; Sobrino et al. 2013; van Hove et al. 2015) or in winter (Montávez et al. 2000; Jauregui 1997), even though in some of these works it is reported that the process reverses during the day generating negative urban heat islands, which gather in the early hours, mainly in temperate, tropical and arid climates, and their causes are attributed to factors such as slow heat absorption by the materials of the city, shade generated by tall buildings, wetness levels in the urban soil in relation to the rural, scarce vegetation in nonurban zones and wind and cloud conditions (Oke 1982; Peña and Romero 2005; Peña 2008; Sobrino et al. 2013).

In MAT, daytime negative UHI's occur in spring and winter, which correspond to the dry season of the place (December-June), this way the factors that can condition their presence are the low levels of wetness in soil and scarce vegetation.

Although by and large daytime UHI's tend to be negative, other studies demonstrate that the process can develop with positive intensities (Capelli de Steffens et al. 2001) due to the increase in the use of heating systems or the heat source of vehicle traffic. For cities in Mexico daytime, urban heat islands with different seasonality and intensity are also reported, they appear in January with weak intensity (Ballinas and Barradas 2014) and during the wet season with moderate intensity (Vidal and Jáuregui 1991; Jauregui 1997). Voogt (2008) mentions that daytime UHI is weak or negative, because at day the surface accumulates radiative energy that will be released into the atmosphere after dusk (García 2013). In MAT, this behavior occurs in autumn, where there is a weak urban heat island; however, the island produced in summer reaches a strong intensity. The pattern of this last season is explained by that reported by Jauregui et al. (1992), who indicate that UHI's in tropical cities appear with greater intensity in wet seasons than in dry; specifically, daytime islands reach their maximum development in the northern hemisphere in July (as it is the case of the metropolis under study), propitiated by the angle of the sun, as it favors cooling by evaporation in rural zones with vegetation, i.e., in a sunny day in wet season a large proportion of heat is used in the evaporation of the soil, while the urban zones dry faster allowing the radiation to heat surfaces (Jauregui 1997).

Regarding the seasonality of SUHI, the literature indicates they occur both day and night; however, they are 


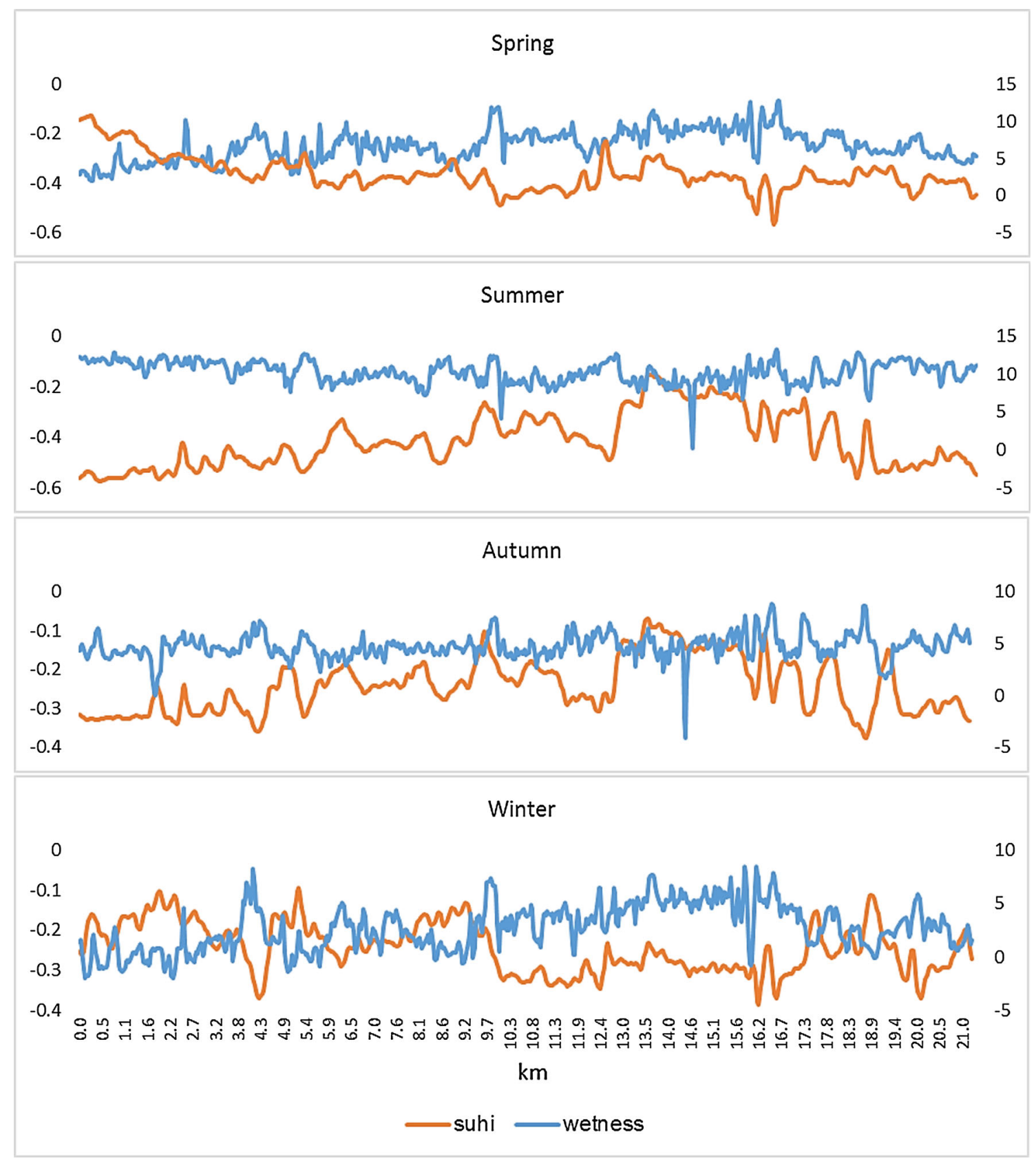

Fig. 6 Soil wetness and SUHI profiles along the study area by season

more intense during the day, mainly in summer (from 10 to $15^{\circ} \mathrm{C}$ in the days and 5 to $10^{\circ} \mathrm{C}$ at night) as solar radiation directly reaches the surfaces, generating important thermal contrasts between wet, dry, with or without vegetation (Voogt 2008; EPA 2013). The behavior in MAT has similar characteristics, as it is in this sort of island where the highest values take place, reaching up to $19^{\circ} \mathrm{C}$ of intensity in summer and $17^{\circ}$ in autumn. Some works report the same pattern of MAT, in which the maximum intensities are reached in summer (Gedzelman et al. 2003 cited in Sarricolea and Romero 2010; Li et al. 2014) or in wet season, which does not properly correspond to summer (Peña and Romero 2005; Sarricolea and Romero 2010).

\section{Relation of surface urban heat island with soil wetness green areas and winds}

The characteristics of the surface and atmosphere are decisive in the processes of formation of heat islands and their intensity. The relationship between soil wetness, green areas and the direction and intensity of winds with respect to temporal and spatial behavior of UHI and SUHI was analyzed. 
In order to determine whether the seasonality pattern of the positive and negative surface urban heat island in Toluca is related to wet or dry season, a tasseled cap transformation was applied to the Landsat satellite images to analyze the values for soil wetness in relation to surface temperature. On the basis of the resulting product, a northto-south profile was marked for the two variables, which started in the rural zone $(0-5 \mathrm{~km})$, crossed the urban area (from 5 to $18 \mathrm{~km}$ ) and ended in the periphery. The obtained graphs show that the relation between temperature and wetness is inversely proportional, this is to say, as wetness increases, temperature drops, and vice versa. The behavior of SUHI's for wet or dry season, previously described, is clearly observed in Fig. 6, the temperature in the rural zone impacts the intensity of the urban heat island in the urban zone. In spring and winter, the values of wetness in the periphery are lower than in the urban environment, having higher temperatures values in rural zones than in the city because in dry soils heating takes place faster than in the artificial surface; this becomes the existence of weak or negative heat islands in the urban environment. When the values of humidity are higher in rural zones (summer and autumn), temperature drops considerably because the radiative energy that reaches the rural surface is largely spent on evapotranspiration processes, enabling the formation of stronger SUHI's in the urban environment.

In order to identify the dependence between temperature and wetness, a lineal regression analysis was carried out at a 95\% confidence level (Fig. 7). The results indicate that for spring and winter there is a coefficient of determination of 0.8 ; i.e., $80 \%$ of the temperature cases are explained from wetness. In summer, slightly more than $50 \%(0.54)$ shows a significant relation, and for autumn $r^{2}$ is 0.65 . The $p$ value is $<0.001$, for the four seasons, which shows that the results are statistically significant; this is to say, the relation between the selected variables is demonstrated.

It has been shown that urban vegetation significantly reduces the intensity of the heat island (Barradas 2013; Colunga et al. 2015; van Hove et al. 2015; Ballinas and Barradas 2016). Therefore, the green areas were identified within the MAT to analyze whether there is a relationship between green areas and heat islands behavior. Total area with green areas within MAT is $12.3 \mathrm{~km}^{2}$. A spatial analysis was performed to detect areas where persistence of UHI and SUHI with strong to very strong intensities $\left(>4{ }^{\circ} \mathrm{C}\right)$ were present throughout the year. From the resulting polygons, Euclidean distance to the green areas was calculated to determine their proximity and verify their influence on the behavior and distribution of the islands (Fig. 8). The map shows that the formation of daytime heat islands with high intensities occurs in remote areas of vegetated areas. Daytime UHI is approximately 6 and $9 \mathrm{~km}$ away from the nearest green area. Spatially the SUHI is more variable, presenting micro-islands throughout the territory. The nearest green areas to the major surface of the heat island are more than $6 \mathrm{~km}$ away. The night-time UHI with greater intensity at $4{ }^{\circ} \mathrm{C}$ is within a buffer of 1-3 $\mathrm{km}$ for green areas, so be expected to decrease the
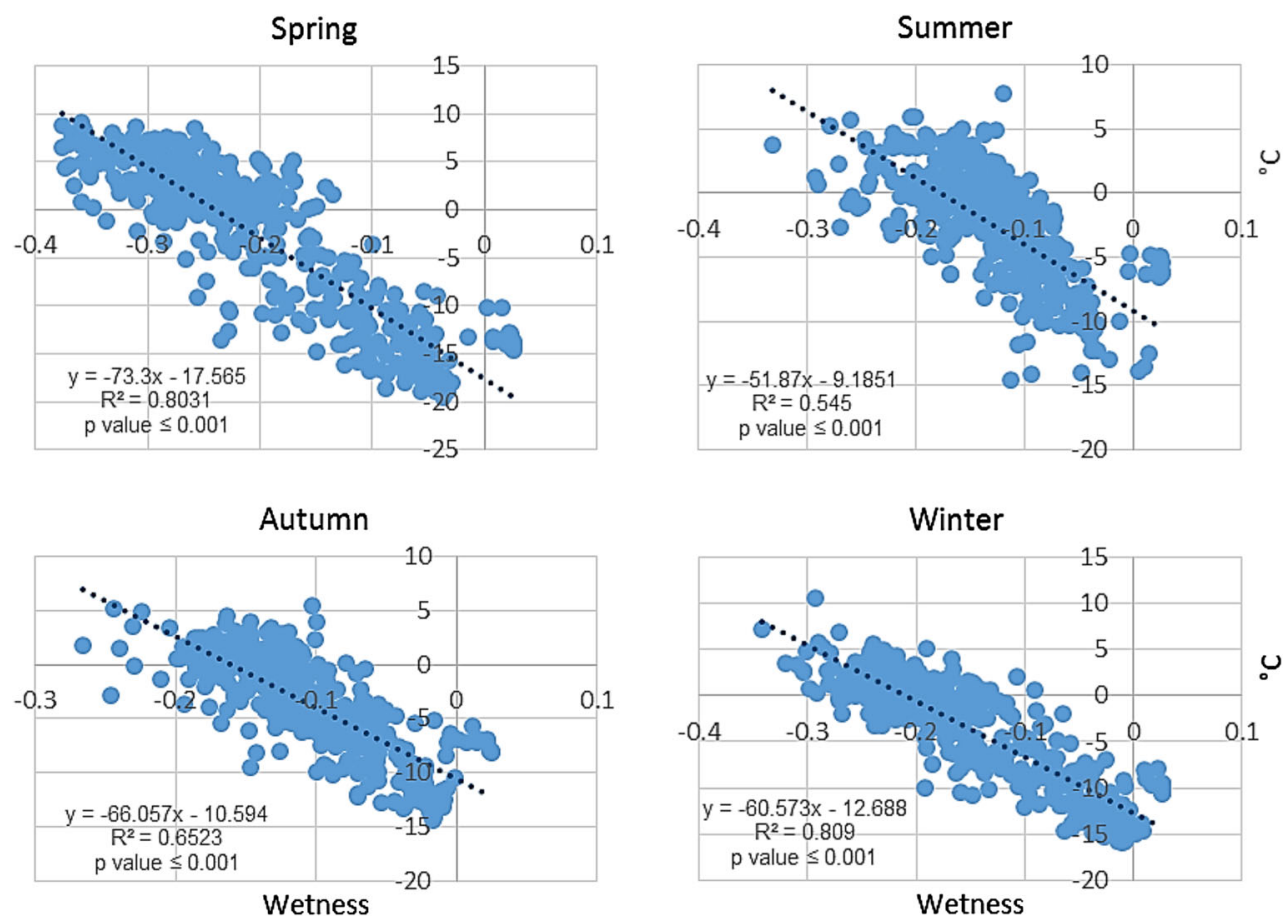

Fig. 7 Linear regression analysis between surface urban heat island intensity and soil wetness 


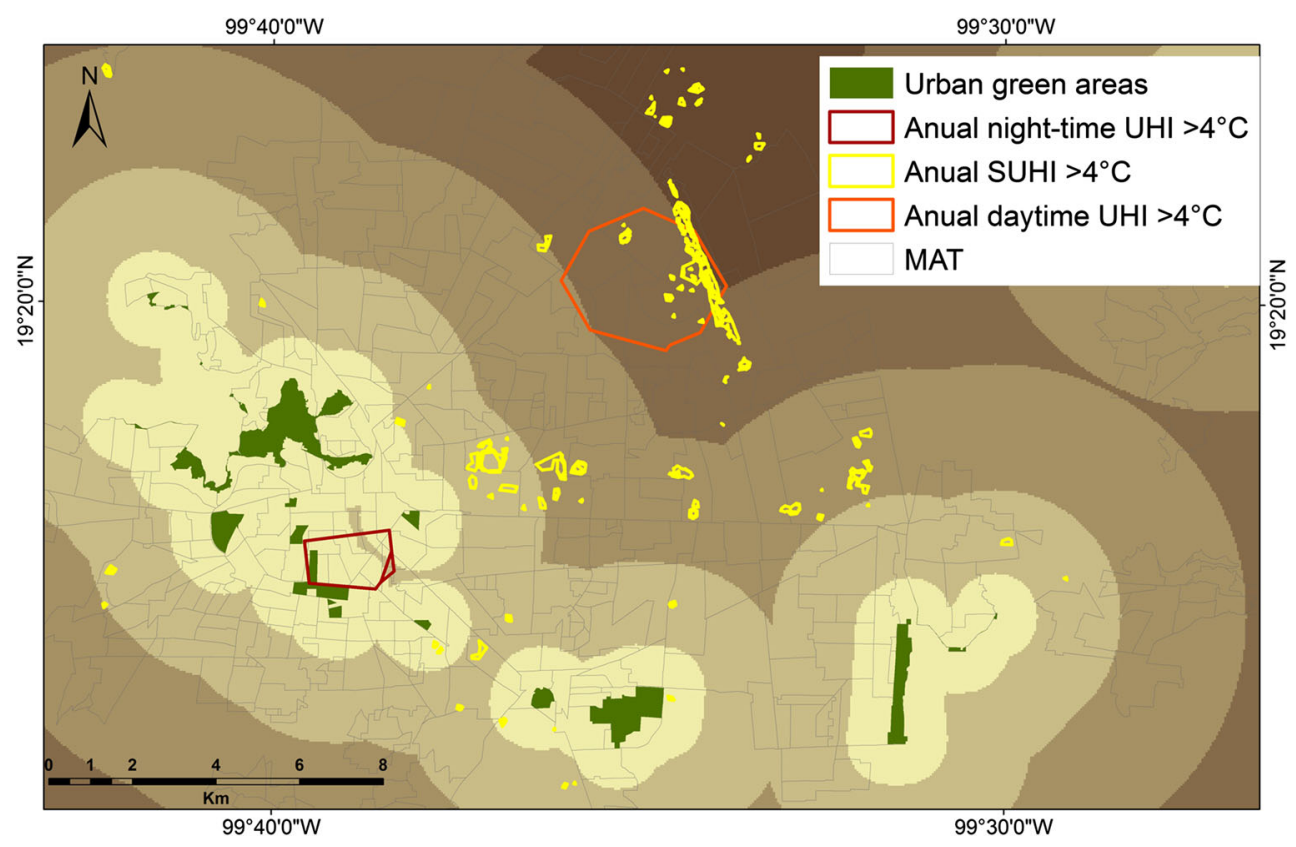

Fig. 8 Distance between green areas and annual heat islands with strong intensity

intensity, however, to observe the behavior of nocturnal islands, shows a uniform approach for the territory distribution. As mentioned above, is at night when the entire radiative energy accumulated in the surfaces is released. This process within MAT expands equally in the territory, even when there are green areas in some places, so it will be necessary include in a future analysis other variables as characteristics and function of surface materials to explain the behavior. Overall it is shown that there is no persistence of high intensities of heat islands in areas close to the green areas.

Speed and wind direction will determine the existence, intensity and distribution of UHI's in the territory, because windy conditions can reduce or dissipate the UHI and wind direction will displace the UHI to prevailing wind direction (Gedzelman et al. 2003). Therefore, spatial behavior of winds in MAT was represented for each of the dates analyzed throughout the year, regarding the distribution of the islands (Fig. 9). A same behavior between the direction wind speeds with the greater intensity areas of the heat island was detected in three seasons. Cooling areas where the air comes and concentration of heat to the same wind direction are identified. In spring, the wind direction comes from the northwest with greater speed and in the same direction where the greatest intensity is presented. During summer, despite having the highest wind speeds $(4.3 \mathrm{~m} / \mathrm{s})$, also the maximum annual intensities daytime UHI are reached, the wind direction comes from the south, the wind speed decreases as temperatures increase, which does not allow dissipation of the island. In autumn, more dynamism occurs in the winds, although the pattern is repeated, showing the direction of the maximum speed toward the zone of greater intensity of the island. The only season that does not show the same behavior is winter, because the direction of maximum winds speeds is opposed to the higher intensities heat island. Wind speed is influence by two wind regulatory forces, air turbulence and surface roughness. For the study area may affect high temperatures in increasing turbulence causing decrease in wind speed, further analysis of surface roughness will be necessary.

\section{Conclusions}

The Metropolitan Area of Toluca has generated a local change in the regional climate, propitiating an urban climate, which was analyzed through its main indicator, the heat islands both atmospheric and superficial. UHI's persist at night throughout the year, reaching a peak in autumn. The literature indicates that the diurnal atmospheric heat islands are difficult to form due to the scarce radiation emitted from the surface to the atmosphere in the early hours of the day; however, the conditions of the zone allow weak and strong urban heat islands to consolidate in the city in autumn and summer. The SUHI's reach the highest intensity values in the summer (of up to $19.2{ }^{\circ} \mathrm{C}$ of difference). The seasonality of the urban heat island phenomenon is determined in summer and autumn, as it is on these seasons when the three sorts of heat islands are produced with higher intensities for each sort. The absence of green areas in the city allows persistence of heat islands with intensity from strong to very strong $\left(>4{ }^{\circ} \mathrm{C}\right)$, and 


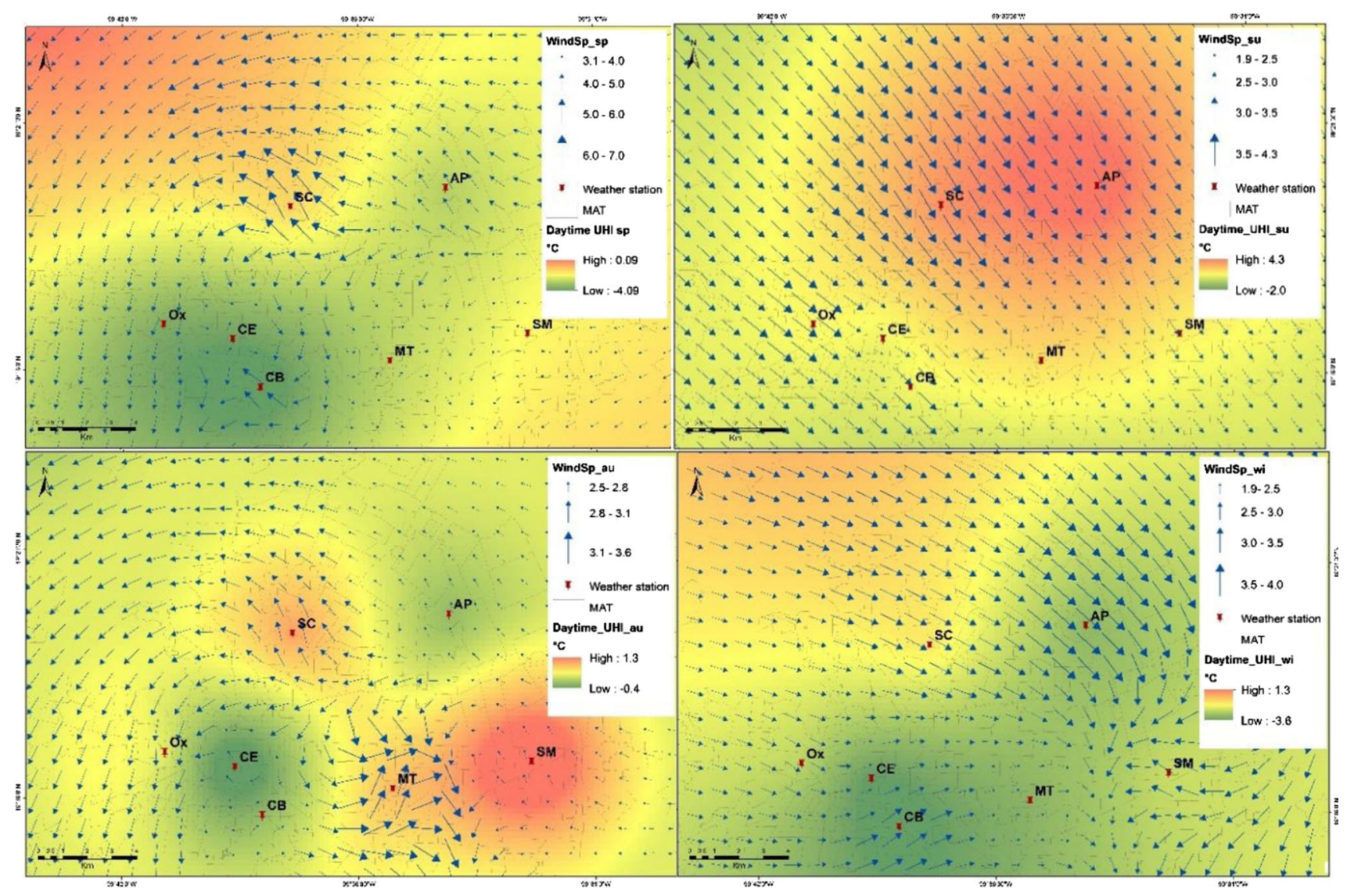

Fig. 9 Wind spatial behavior in MAT

nearest vegetation zone is $6 \mathrm{~km}$ from the representative heat islands. Soil wetness in the rural area determines the intensity of the surface urban heat islands due to the differences with respect to the thermal inertia reached for wet and dry areas. It is detected the formation of non-urban heat islands with very strong intensity in dry season (winter-spring) which impacts on the formation of negative heat islands in the city. The wind influences the distribution of UHI's in MAT because it concentrates the heat in the direction it has. A pattern is detected where the wind speed decreases in the zones of maximum temperature, allowing the formation of the phenomenon.

\section{References}

Alonso MS, Labajo JL, Fidalgo MR (2003) Characteristics of the urban heat island in the city of Salamanca (Spain). Atmósfera 16(3):137-148

Anderson S (2002) An evaluation of spatial interpolation methods on air temperature in Phoenix, AZ. Department of Geography, Arizona State University. http://www.cobblestoneconcepts. com/ucgis2summer/anderson/anderson.htm Accessed 21 Oct 2015
Arnfield AJ (2003) Two decades of urban climate research: a review of turbulence, exchanges of energy and water, and the urban heat island. Int J Climatol 23(1):1-26. doi:10.1002/joc.859

Ballinas M, Barradas V (2014) The actual urban heat island in Mexico City. http://www.researchgate.net/profile/Victor_Barradas3/publi cation/270050061_The_actual_urban_heat_island_in_Mexico_ City/links/549ef0870cf267bdb8fdb96e.pdf. Accessed 12 Feb 2015

Ballinas M, Barradas V (2016) The urban tree as a tool to mitigate the urban heat island in Mexico city: a simple phenomenological model. J Environ Qual 45:157-166. doi:10.2134/jeq2015.01.0056

Barradas V (2013) La isla de calor urbana y la vegetación arbórea. http://web.ecologia.unam.mx/oikos3.0/index.php/oikos-histor ico/numeros-anteriores/47-la-isla-de-calor-urbana-y-la-vegeta cion-arborea. Accessed 18 Aug 2016

Capelli de Steffens A, Píccolo M, Hernández J, Navarrete G (2001) La isla de calor estival en Temuco, Chile. Papeles de Geografía 33:49-60

Chuvieco E (2002) Teledetección ambiental, la observación de la tierra desde el espacio. Ariel, Barcelona

Colunga ML, Cabromón-Sandoval V, Suzán-Azpiri H, GuevaraEscobar A, Luna-Soria H (2015) The role of urban vegetation in temperature and heat island effects in Querétaro city, Mexico. Atmósfera 28(3):205-218

EPA (2013) Heat island effect—basic information. www.epa.gov

Fernández F (1995) Manual de climatología aplicada: clima, medio ambiente y planificación. Síntesis, Madrid

Fernández F, Martilli A (2012) El clima urbano: aspectos generales y su aplicación en el área de Madrid. Indice 50:21-24

García M (2013) Clima urbano costero de Mar del Plata y NecocheaQuequén. GAEA, Buenos Aires 
García-Cueto O, Jáuregui-Ostos E, Toudert D, Tejeda-Martínez A (2007) Detection of the urban heat island in Mexicali, B.C., México and its relationship with land use. Atmósfera 20(2):111-131

Gedzelman S, Austin S, Cermak R, Stefano N, Partridge S, Quesenberry S, Robinson D (2003) Mesoscale aspects of the urban heat island around New York city. Theor Appl Climatol 75:29. doi:10.1007/s00704-002-0724-2

GEM and COESPO (2012) Zona Metropolitana de Valle de Toluca. Aspectos sociodemográficos. Gobierno del Estado de México, Estado de México

Gillespie AR (1985) Lithologic mapping of silicate rocks using TIMS. In: Proceedings of the thermal infrared multispectral scanner. TIMS data user's workshop, Jet Propulsion Laboratory, Pasadena, pp 29-44

Gioia A, Paolini L, Malizia A, Oltra-Carrió R, Sobrino JA (2014) Size matters: vegetation patch size and surface temperature relationship in foothills cities of northwestern Argentina. Urban Ecosyst 17(4):1161-1174. doi:10.1007/s11252-014-0372-1

Jauregui E (1997) Heat island development in Mexico city. Atmos Environ 31(22):3821-3831. doi:10.1016/S1352-2310(97)00136-2

Jauregui E (2005) Possible impact of urbanization on the thermal climate of some large cities in México. Atmósfera 18(4):249-252

Jauregui E, Godinez L, Cruz F (1992) Aspects of heat-island development in Guadalajara, Mexico. Atmos Environ Urban Atmos 26B(3):391-396. doi:10.1016/0957-1272(92)90014-J

Jiménez-Muñoz JC, Sobrino JA, Gillespie A, Sabol D (2003) Separación emisividad/temperatura a partir de datos DAIS y aplicación del contraste espectral para discriminar distintos tipos de vegetación. Revista de Teledetección 19:51-58

Jiménez-Muñoz JC, Sobrino JA, Cristóbal J, Sòria G, Ninyerola M, Pons X, Hidalgo V, Franch B, Romaguera M, Oltra-Carrió R, Julien Y, Mattar C (2010) Obtención de la temperatura de la superficie terrestre a partir de la serie histórica LANDSAT. Revista de Teledetección 33:53-63

Li C-f, Shen D, Dong J-s, Yin J-y, Zhao J-j, Xue D (2014) Monitoring of urban heat island in Shanghai, China, from 1981 to 2010 with satellite data. Arab J Geosci 7:3961-3971. doi:10.1007/s12517013-1053-8

López A, Fernández F, Arroyo F, Martín J, Cuadrat JM (1993) El clima de las ciudades españolas. Cátedra. Madrid

Montávez J, Rodríguez A, Jiménez J (2000) A study of the urban heat island of Granada. Int J Climatol 20:899-911. doi:10.1002/10970088(20000630)20:8<899::AID-JOC433>3.0.CO;2-I

Morales C, González L, Madrigal D (2007) Isla de calor en Toluca, México. Ciencia Ergo Sum 14(3):307-316

Nichol J, Yee Fung W, Lam K, Wong S (2009) Urban heat island diagnosis using ASTER satellite images and 'in situ' air temperatura. Atmos Res 94:276-284. doi:10.1016/j.atmosres. 2009.06.011

Oke TR (1982) The energetic basis of the urban heat island. Q J R Meteorol Soc 108:1-24. doi:10.1002/qj.49710845502

Oke TR (1987) Boundary layer climates, 2nd edn. Routledge, London

Oke TR, Hannell F (1970) The form of the urban heat island in Hamilton, Canada, en urban climates (vol 108). WMO technical note, pp 113-126

Olalla F, Calera A (2005) Uso de la teledetección en el seguimiento de los cultivos de regadío. En: Agua y agronomía. Mundi Prensa Libros S.A., Madrid

Peña MA (2008) Relationships between remotely sensed surface parameters associated with the urban heat sink formation in Santiago, Chile. Int J Remote Sens 29(15):4385-4404. doi:10. 1080/01431160801908137

Peña MA, Romero H (2005) Relación espacial y estadística entre las islas de calor de superficie, coberturas vegetales, reflectividad y contenido de humedad del suelo, en la ciudad de Santiago y su entorno rural. Anales de la Sociedad Chilena de Ciencias Geográficas 2005:107-118

Romero H, Salgado M, Smith P (2010) Cambios climáticos y climas urbanos. Relaciones entre zonas termales y condiciones socioeconómicas de la población de Santiago de Chile. INVI 25(70):151-179

Roy DP, Wulder MA, Loveland TR, Woodcock CE, Allen RG, Anderson MC, Helder D, Irons JR, Johnson DM, Kennedy R, Scambos TA, Schaaf CB, Schott JR, Sheng Y, Vermote EF, Belward AS, Bindschadler R, Cohen WB, Gao F, Hipple JD, Hostert P, Huntington J, Justice CO, Kilic A, Kovalskyy V, Lee ZP, Lymburner L, Masek JG, McCorkel J, Shuai Y, Trezza R, Vogelmann J, Wynne RH, Zhu Z (2014) Landsat-8: science and product vision for terrestrial global change research. Remote Sens Environ 145:154-172. doi:10.1016/j.rse.2014.02.001

Ruiz-Flaño P, Romero L, Máyer P, Hernández A (2008) Las islas de calor en las Palmas de Gran Canaria: intensidad, distribución y factores condicionantes. Boletín de la AGE 47:157-173

Sarricolea P, Martín-Vide J (2013) La isla de calor urbana del área metropolitana de Santiago (AMS) de Chile a partir de diferencias térmicas de los observatorios de Talagante y Cerrillos. Perspectiva Geográfica 18(2):239-256. doi:10.19053/01233769.2677

Sarricolea P, Martín-Vide J (2014) El estudio de la isla de calor urbana de superficie del Área Metropolitana de Santiago de Chile con imágenes Terra-MODIS y análisis de componentes principales. Revista de Geografía Norte Grande 57:123-141. doi:10.4067/S0718-34022014000100009

Sarricolea P, Romero H (2010) Análisis de los factores condicionantes sobre las temperaturas de emisión superficial en el área metropolitana de Valparaíso Chile. ACE 14:79-96

SEDESOL, CONAPO, INEGI (2012) Delimitación de las zonas metropolitanas de México 2010. SEDESOL, CONAPO, INEGI. México

Sobrino J, Oltra-Carrió R, Sòria G, Jiménez-Muñoz J, Franch B, Hidalgo V, Mattar C, Julien Y, Cuenca J, Romaguera M, Gómez J, De Miguel E, Bianchi R, Paganini M (2013) Evaluation of the surface urban heat island effect in the city of Madrid by thermal remote sensing. Int J Remote Sens 34(9-10):3177-3192. doi:10. 1080/01431161.2012.716548

UN-HABITAT (2012) Estado de las ciudades de América Latina y El Caribe 2012, rumbo a una nueva transición urbana. UNHABITAT, Kenia

USGS (2015) Landsat 8 (L8) data user handbook. http://landsat.usgs. gov/documents/Landsat8DataUsersHandbook.pdf. Accessed 18 Sep 2015

van Hove LWA, Jacobs CMJ, Heusinkveld BG, Elbers JA, van Driel BL, Holtslag AAM (2015) Temporal and spatial variability of urban heat island and thermal comfort within the Rotterdam agglomeration. Build Environ 83:91-103. doi:10.1016/j.buil denv.2014.08.029

Vidal J, Jáuregui E (1991) Evolución de la isla de calor en Toluca Mex. observatoriosgeograficoamericalatina.org.mx/egal3/Proce sosambientales/Climatología. Accessed 2 Sep 2015

Voogt J (2008) Urban heat islands: hotter cities. http://www.action bioscience.org/environment/voogt.html. Accessed 21 Apr 2015

Voogt J, Oke TR (2003) Thermal remote sensing of urban climates. Remote Sens Environ 86(3):370-384. doi:10.1016/S00344257(03)00079-8

Zhang J, Wang Y (2008) Study of the relationships between the spatial extent of surface urban heat islands and urban characteristic factors based on landsat ETM+ data. Sensors 8:7453-7468. doi:10.3390/s8117453

Zhao L, Lee X, Smith R, Oleson K (2014) Strong contributions of local background climate to urban heat islands. Nature 511(7508):216-219. doi:10.1038/nature13462 